\title{
Investigations on the Formation of Copper Polyvanadates as a Function of pH
}

\author{
Shiva Prasad ${ }^{*, a}$, André L. F. Brito ${ }^{a}$, Ana C. S. Muniz ${ }^{a}$ and Valderí D. Leite \\ ${ }^{a}$ Departamento de Engenharia Química, Universidade Federal da Paraíba-Campus II, CP 10108, 58109-970 \\ Campina Grande - PB, Brazil \\ ${ }^{b}$ Departamento de Química, Universidade Estadual da Paraíba, 58100-000 Campina Grande - PB, Brazil
}

\begin{abstract}
A formação e composição de vanadatos de cobre obtidos pela interação de sulfato de cobre com diferentes vanadatos de sódio (orto, piro, meta e poli) foram investigadas por técnicas eletrométricas envolvendo titulações condutométricas e pH-métricas entre reagentes a várias concentrações em meios aquoso e aquoso-etanólico. As inflexões e degraus bem definidos nas curvas de titulações fornecem evidências incontestáveis sobre a formação e precipitação de vanadatos orto-3CuO. $\mathrm{V}_{2} \mathrm{O}_{5}$, piro- $2 \mathrm{CuO} . \mathrm{V}_{2} \mathrm{O}_{5}$ e meta-CuO. $\mathrm{V}_{2} \mathrm{O}_{5}$ de cobre nas vizinhanças dos $\mathrm{pH}$ 's 8,$1 ; 7,4$ e 6,2 , respectivamente. Os estudos sobre formação de poli-vanadato não forneceram resultados confiáveis. As investigações analíticas sobre os compostos formados confirmaram os resultados do estudo eletrométrico. A precipitação de orto-vanadato de cobre foi quase quantitativa e as titulações $\mathrm{pH}$ métricas fornecem um método rápido e simples para determinação de vanádio(V) em soluções.
\end{abstract}

The formation and composition of copper vanadates obtained by the interaction of copper sulfate with different sodium vanadates (ortho, pyro, meta and poly) have been studied by means of electrometric techniques involving glass electrode and conductometric titrations between the reactants at several concentrations in aqueous and aqueous-ethanolic media. The well defined inflections and breaks in the titration curves provide cogent evidence for the formation and precipitation of copper ortho- $3 \mathrm{CuO} . \mathrm{V}_{2} \mathrm{O}_{5}$, pyro- $2 \mathrm{CuO} . \mathrm{V}_{2} \mathrm{O}_{5}$ and meta-CuO. $\mathrm{V}_{2} \mathrm{O}_{5}$ vanadates in the vicinity of $\mathrm{pH} 8.1,7.4$ and 6.2, respectively. The studies on formation of copper poly-vanadate failed to give any dependable results. Analytical investigations of the compounds formed confirm the results of the electrometric study. The precipitation of copper ortho-vanadate is almost quantitative and the glass electrode titrations ofers a simple and rapid method for determination of vanadium(V) in solutions.

Keywords: polyvanadates, vanadates, copper, electrometry

\section{Introduction}

During the last decade a new interest in the chemistry of vanadium has developed. ${ }^{1,2}$ This has arisen in part from antiviral, including anti-AIDS activity of vanadates and their interaction with biological molecules like proteins. ${ }^{3,4}$ Vanadium also exhibits catalytic properties in an extensive variety of chemical reactions. These include the use of vanadium oxide as catalyst in the following: sulfur dioxide to the trioxide, the sulfonation of aromatic hydrocarbons or of pyridine, the reduction of olefines; the oxidation of hydroiodic acid by hydrogen peroxide, of sugar by nitric acid, of alcohol by air, of stannous salts by nitric acid, of cyclic organic compounds by hydrogen peroxide, of naphthalene by air, and the reduction of aromatic hydrocarbons by hydrogen. ${ }^{5} \mathrm{~A}$ number of recent studies

\footnotetext{
* e-mail: prasad@deq.ufpb.br
}

have shown that vanadium oxide catalyst is very promising in oxidative dehydrogenation of alkanes but its activity and selectivity depend on the manner in which the catalyst is pretreated. ${ }^{6-10}$ The structure of the vanadia is a very important factor. ${ }^{9,10}$ Khodakov et al. ${ }^{11}$ have recently determined that the oxidative dehydrogenation rates of propane increase as the size of poly-vanadate domain increases. Efforts aimed at relating the structures of the vanadium species to its catalytic activity and selectivity suggest that the catalytic performance depends on the type of structure, bond length and distance between active and selective sites. ${ }^{6-15}$

In highly alkaline solution, $\mathrm{pH}>14$, vanadium(V) exists as a tetrahedral $\mathrm{VO}_{4}^{3-}$ anion. ${ }^{16}$ On acidification the aqueous solutions turn from colorless to orange-yellow polymeric species. A survey of literature suggests the occurrence of a series of alkali metal vanadates having the ratio of $\mathrm{Na}_{2} \mathrm{O}: \mathrm{V}_{2} \mathrm{O}_{5}$ as 3:1, 2:1, 1:1, 1:2, 1:2.5, 1:3, 2:3 etc. 
in solution under different conditions. The existence of so many polymeric species seems to be doubtful; moreover, there is a great variance in the results published by earlier workers, which allows no satisfactory interpretation of the mechanism of the condensation process. A further verification of the vanadate system seems very desirable with a view to rationalizing the conflicting details of the previous workers by employing electrometric techniques, which have provided more conclusive evidences on such systems. ${ }^{17-19}$ The knowledge on the formation of different species under different conditions will help in the explanation of the catalytic performance of vanadium and may be a key to understanding the catalytic mechanism. In an earlier publication the results on effect of $\mathrm{pH}$ change on solutions of $\mathrm{Na}_{3} \mathrm{VO}_{4}$ and composition of lead vanadates have been reported. ${ }^{20}$ The results obtained on formation of copper vanadates are presented here.

\section{Experimental}

$\mathrm{V}_{2} \mathrm{O}_{5}, \mathrm{NaOH}, \mathrm{CuSO}_{4} .5 \mathrm{H}_{2} \mathrm{O}, \mathrm{Na}_{2} \mathrm{WO}_{4} .2 \mathrm{H}_{2} \mathrm{O}$, ethanol, sulfuric acid, phosphoric acid and sodium quinaldinate of extra-pure grade were used and their solutions were prepared with deionized distilled water. The solution of sodium ortho-vanadate $\mathrm{Na}_{3} \mathrm{VO}_{4}$ was prepared by digesting one mole of $\mathrm{V}_{2} \mathrm{O}_{5}$ in boiling solution of $\mathrm{NaOH}$ containing six moles of it. Sodium pyro, meta and poly-vanadate solutions were prepared by adding sulfuric acid to orthovanadate solution at $100{ }^{\circ} \mathrm{C}$ in molar ratios $1 \mathrm{H}: 1 \mathrm{~V}, 2 \mathrm{H}: 1 \mathrm{~V}$ and $2.6 \mathrm{H}: 1 \mathrm{~V}$, respectively. ${ }^{20}$

$\mathrm{pH}$ measurements were carried out on Metrohm Herisau pH-meter using Scott Gerate glass combination electrode. Stoichiometric points were obtained from the sharp inflections in the titration curves. The inflections obtained in the curves were confirmed by the pronounced maxima in $\mathrm{dpH} / \mathrm{dV}$ graphs. Conductance values were recorded by employing a Metrohm conductometer. Conductivity values after correcting for dilution effect were plotted as a function of $\mathrm{mL}$ of titrant solution added and the end-points were judged from the breaks in titration curves. A series of $\mathrm{pH}$ and conductometric titrations were performed by direct and reverse methods, i.e. when copper sulfate solution from the microburette was added to sodium vanadate solution and vice-versa. The highest error in equivalence point measurements by $\mathrm{pH}$ and conductance techniques was of $\pm 0.01 \mathrm{~mL}$. $25 \mathrm{~mL}$ of ethanolic solution (20\%) was taken in the cell, which was thermostated at $25.0 \pm 0.1^{\circ} \mathrm{C}$. The same strengths of solutions were employed in both techniques for the sake of comparison of results. The electrometric titration results are summarized in Table 1.

Table 1. Summary of results of electrometric study on formation of copper vanadates. Volume of titre solution taken in the cell $=25 \mathrm{~mL}$

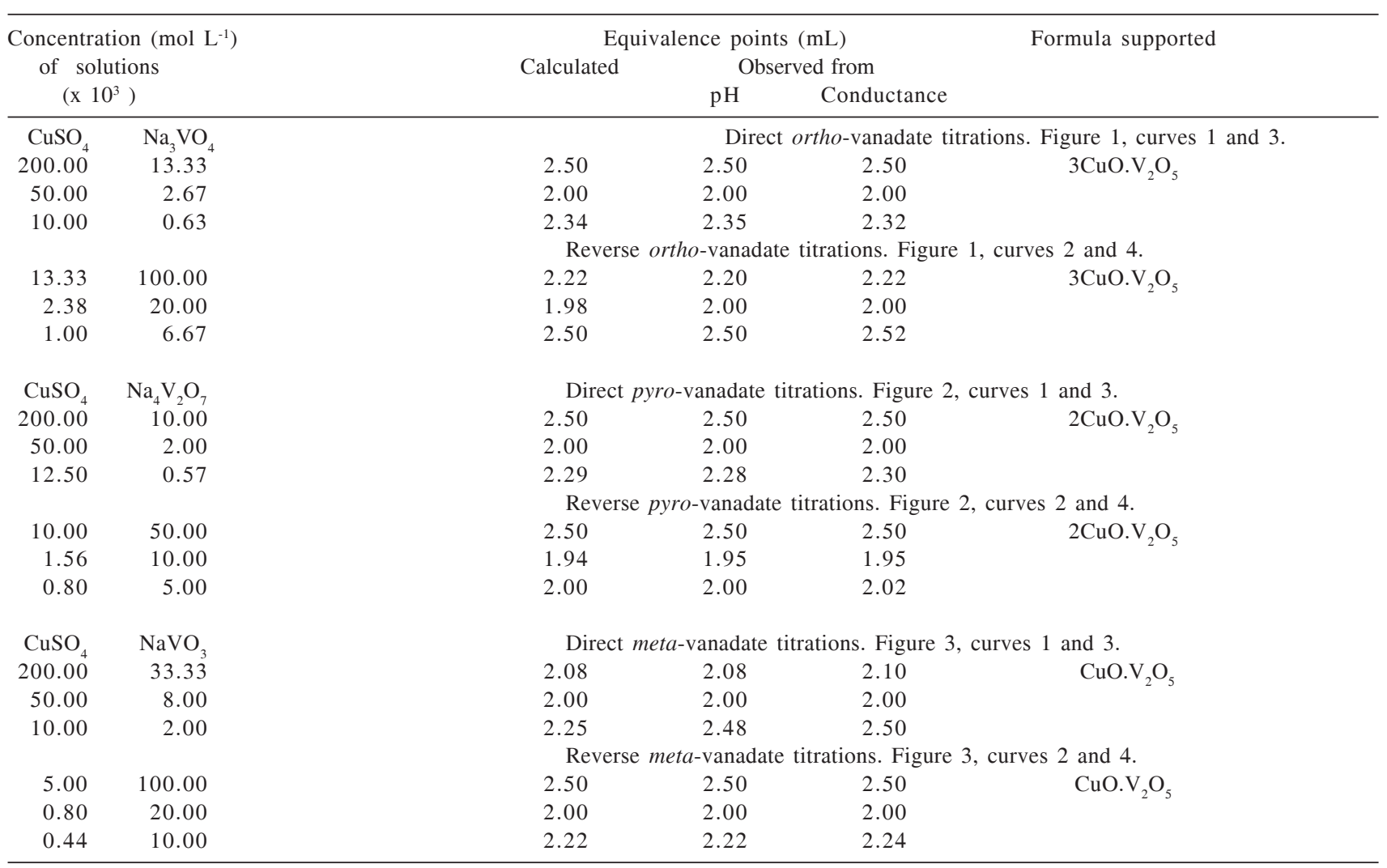


The precipitates obtained at the end-points of titrations between copper sulfate and sodium vanadates were also analyzed to substantiate the electrometric results. The different copper vanadates were prepared by mixing stoichiometric amounts of copper sulfate solution with the respective sodium vanadate solutions. The precipitates obtained were washed several times with $20 \%$ ethanolic solution and dried in a vacuum desiccator for $40 \mathrm{~h}$. A known amount (ca. $2 \mathrm{~g}$ ) of each of the above precipitates was dissolved in a minimum quantity of sulfuric acid and then analyzed quantitatively for copper by quinaldinate ${ }^{21}$ and vanadium spectrophotometrically by phosphotungstate method. ${ }^{21}$ From the proportions of copper and vanadium in the compounds thus obtained their composition was established. The results are summarized in Table 2.

\section{Results and Discussion}

In an earlier publication ${ }^{20}$ Prasad et al. have shown that the addition of acid to sodium ortho-vanadate and alkali to $\mathrm{V}_{2} \mathrm{O}_{5}$ solutions at room temperature causes the formation of various poly-anions of uncertain compositions, but when the solutions were heated after each addition of titrant the three different vanadates, namely pyro $\left(\mathrm{Na}_{4} \mathrm{~V}_{2} \mathrm{O}_{7}\right)$, meta $\left(\mathrm{NaVO}_{3}\right)$ and poly $\left(\mathrm{Na}_{4} \mathrm{H}_{2} \mathrm{~V}_{10} \mathrm{O}_{28}\right)$ are formed in the $\mathrm{pH}$ ranges 10.1-10.7, 7.0-7.5 and 3.4-3.8, respectively. Hence it was considered of interest to ascertain whether similar vanadates of heavy metals may be precipitated as a result of double decomposition. The reaction between alkali vanadates and copper sulfate has therefore been studied by means of $\mathrm{pH}$ and conductometric titrations with regard to changes occurring in $\mathrm{H}^{+}$concentration and to the composition of the precipitate formed.

\section{Ortho-vanadate titrations}

The $\mathrm{pH}$ of copper sulfate and sodium ortho-vanadate solutions was measured and found in the vicinity of 5.2

Table 2. Summary of analytical results of the precipitates of copper vanadates

\begin{tabular}{lclc}
\hline $\begin{array}{l}\text { Proposed formula } \\
\text { of the compound }\end{array}$ & Mode of analysis & \multicolumn{1}{c}{ Analysis \%: Found (Calculated) } \\
\hline & & Analysis of copper ortho-vanadate precipitates. \\
$3 \mathrm{CuO} . \mathrm{V}_{2} \mathrm{O}_{5}$ & Direct $^{\mathrm{a}}$ & $45.29(45.33)$ & $24.26(24.23)$ \\
& Reverse $^{\mathrm{b}}$ & 45.38 & 24.18 \\
& & Analysis of copper pyro-vanadate precipitates. \\
$2 \mathrm{CuO} . \mathrm{V}_{2} \mathrm{O}_{5}$ & Direct & $37.22(37.27)$ & $29.93(29.88)$ \\
& Reverse & 37.33 & 29.84 \\
$\mathrm{CuO} . \mathrm{V}_{2} \mathrm{O}_{5}$ & & Analysis of copper meta-vanadate precipitates. & $39.04(38.97)$ \\
& Direct & $24.27(24.31)$ & 38.90 \\
\hline
\end{tabular}

a Direct - Copper sulfate solution added to sodium ortho-vanadate solution.

${ }^{\text {b }}$ Reverse - Sodium ortho-vanadate solution added to copper sulfate solution.
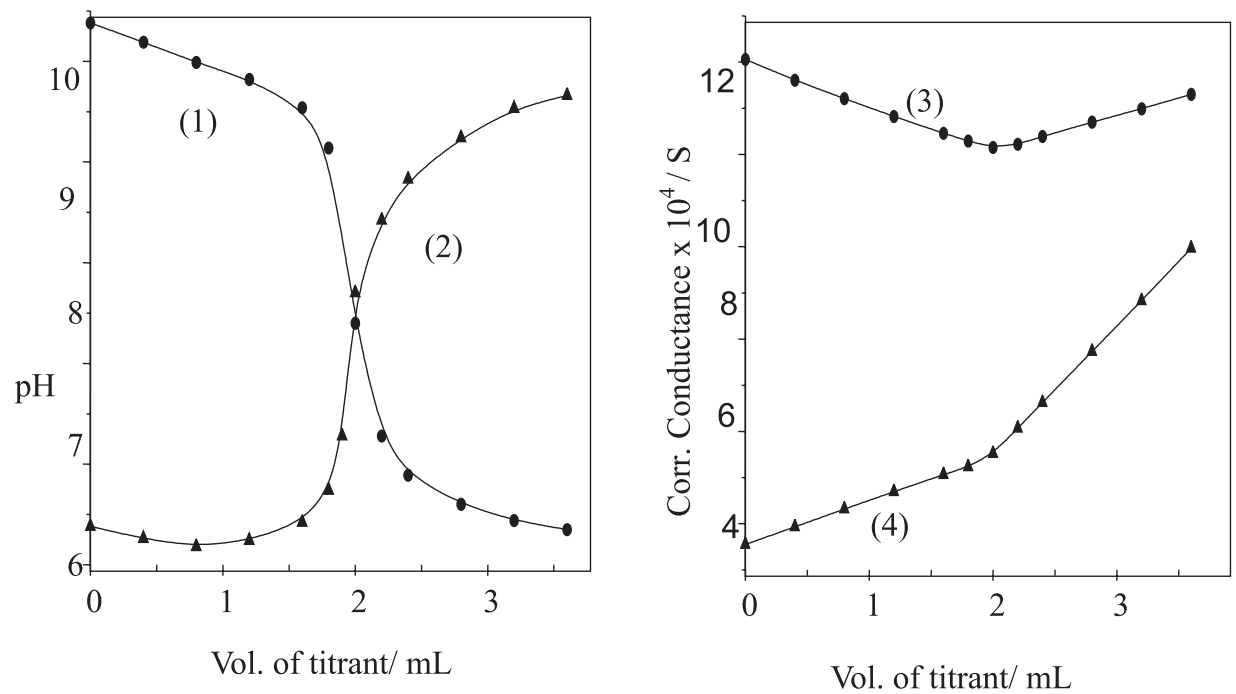

Figure 1. Ortho-vanadate titrations. (1) and (3): $25 \mathrm{~mL}$ of $2.67 \times 10^{-3} \mathrm{~mol} \mathrm{~L}^{-1}$ of $\mathrm{Na}_{3} \mathrm{VO}_{4}$ titrated with $5.00 \times 10^{-2} \mathrm{~mol} \mathrm{~L}^{-1}$ of $\mathrm{CuSO}_{4}$, (2) and (4): $25 \mathrm{~mL}$ of $2.38 \times 10^{-3} \mathrm{~mol} \mathrm{~L}^{-1} \mathrm{CuSO}_{4}$ titrated with $2.00 \times 10^{-2} \mathrm{~mol} \mathrm{~L}^{-1} \mathrm{Na}_{3} \mathrm{VO}_{4}$. 
and 12.3 respectively. Figure 1 (curves 1 and 2) illustrates the changes occurring in the $\mathrm{pH}$ values during the reaction between $\mathrm{Cu}^{2+}$ and $\mathrm{VO}_{4}^{3-}$ ions. In case of direct titrations (curve 1) when copper sulfate solution from the microburette is added to ortho-vanadate solution a gradual decrease in $\mathrm{pH}$ was observed till the stoichiometric endpoint and after which the smallest addition of the titrant causes a sharp fall in $\mathrm{pH}$, indicating the completion of reaction and suggesting the formation of copper orthovanadate in the vicinity of $\mathrm{pH} 8.1$. In the case of reverse titrations (curve 2), when the ortho-vanadate solution was used as titrant the $\mathrm{pH}$ first changes slowly and at the stoichiometric point a marked upward jump in $\mathrm{pH}$ was observed, corresponding to the ratio $\mathrm{Cu}^{2+}: \mathrm{VO}_{4}{ }^{3-}$ as $3: 2$, confirming the formation of the same compound $3 \mathrm{CuO} . \mathrm{V}_{2} \mathrm{O}_{5}$ according to the following equation:

$3 \mathrm{CuSO}_{4}+2 \mathrm{Na}_{3} \mathrm{VO}_{4}=\left(3 \mathrm{CuO} . \mathrm{V}_{2} \mathrm{O}_{5}\right)+3 \mathrm{Na}_{2} \mathrm{SO}_{4}$

Employing similar concentrations of the reactants, both direct and reverse conductometric titrations between the solutions of copper sulfate and sodium ortho-vanadate were also carried out (Figure 1, curves 3 and 4). Well defined breaks in the titration curves were obtained at a 3:2 molar ratio of $\mathrm{Cu}^{2+}: \mathrm{VO}_{4}^{3-}$, which confirm the formation of the identical compound, copper ortho-vanadate $3 \mathrm{CuO} . \mathrm{V}_{2} \mathrm{O}_{5}$. In the direct titrations (curve 3 ) when copper sulfate solution was added from the microburette to the ortho-vanadate solution in the titration cell, a gradual increase in conductance value was observed until the stoichiometric end-point, after which the conductance increased rapidly with the increase in ionic concentration due to completion of the precipitation reaction. In case of reverse titrations (curve 4), as the copper ions are removed in the form of precipitate and more mobile sodium ions are introduced in the solution, the increase in conductance values is comparatively higher from the very beginning.

\section{Pyro-vanadate titrations}

The solution of sodium pyro-vanadate was prepared as described earlier. The direct pH-titration curves (Figure 2, curve 1) are similar to those of the direct ortho-vanadate titration curves, with the inflection corresponding to the ratio $\mathrm{Cu}^{2+}: \mathrm{V}_{2} \mathrm{O}_{7}^{4-}$ as $2: 1$, suggesting the formation of copper pyro-vanadate, $2 \mathrm{CuO} . \mathrm{V}_{2} \mathrm{O}_{5}$, around $\mathrm{pH}$ 7.4. In the case of inverse titrations (Figure 2, curve 2), the first addition of alkali pyro-vanadate ( $\mathrm{pH} \cong 10.4$ ) to copper sulfate solution $(\mathrm{pH} \cong 5.2)$ causes an initial decrease in $\mathrm{pH}$ till about half the volume of titrant required for the precipitation of copper pyro-vanadate, is added. The initial lowering in $\mathrm{pH}$ value is due to the presence of hydrolyzed acid from copper salt. Later on, with the progress of the reaction, $\mathrm{pH}$ begins to rise and a pronounced upward inflection is obtained at the stoichoimetric end-point, corresponding to the formation of copper pyro-vanadate, $2 \mathrm{CuO} . \mathrm{V}_{2} \mathrm{O}_{5}$. The formation of copper pyro-vanadate may be represented as follows:

$$
\begin{aligned}
& \mathrm{H}_{2} \mathrm{SO}_{4}+2 \mathrm{Na}_{3} \mathrm{VO}_{4}=\mathrm{Na}_{4} \mathrm{~V}_{2} \mathrm{O}_{7}+\mathrm{Na}_{2} \mathrm{SO}_{4}+\mathrm{H}_{2} \mathrm{O} \\
& 2 \mathrm{CuSO}_{4}+\mathrm{Na}_{4} \mathrm{~V}_{2} \mathrm{O}_{7}=\left(2 \mathrm{CuO} . \mathrm{V}_{2} \mathrm{O}_{5}\right)+2 \mathrm{Na}_{2} \mathrm{SO}_{4}
\end{aligned}
$$

The course of this reaction was also followed by means
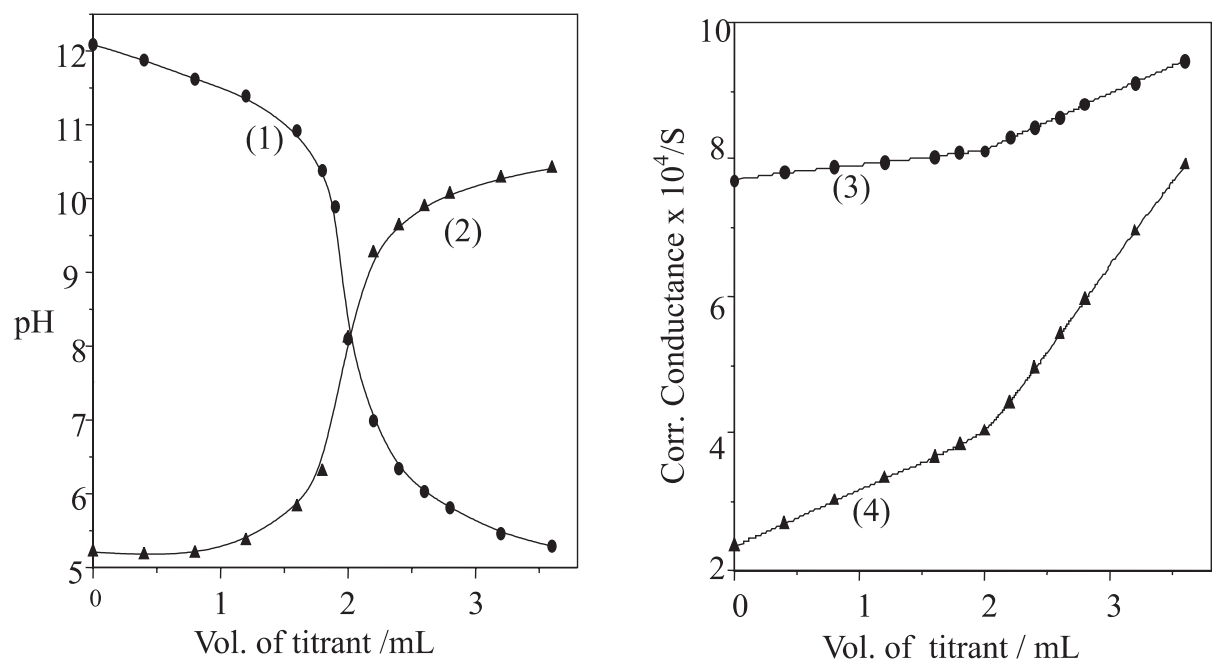

Figure 2. Pyro-vanadate titrations. (1) and (3): $25 \mathrm{~mL}$ of $2.00 \times 10^{-3} \mathrm{~mol} \mathrm{~L}^{-1} \mathrm{Na}_{4} \mathrm{~V}_{2} \mathrm{O}_{7}$ titrated with $2.00 \times 10^{-2} \mathrm{~mol} \mathrm{~L}^{-1} \mathrm{of} \mathrm{CuSO}_{4}$, (2) and (4): 25 $\mathrm{mL}$ of $1.56 \times 10^{-3} \mathrm{CuSO}_{4}$ titrated with $1.00 \times 10^{-2} \mathrm{~mol} \mathrm{~L}^{-1} \mathrm{Na}_{4} \mathrm{~V}_{2} \mathrm{O}_{7}$. 
of conductometric titrations. A sharp break in titration curves (Figure 2, curves 3 and 4) was obtained at a point corresponding to the stoichiometry for the formation of copper pyro-vanadate. In the direct titrations (curve 3), when copper sulfate solution was added from the microburette to the pyro-vanadate solution in the titration cell, a gradual decrease in conductance values was observed (due to removal of $\mathrm{V}_{2} \mathrm{O}_{7}^{4-}$ ions in the form of precipitate) until stoichiometric end-point, after which the conductance increased with the increase in ionic concentration. In case of reverse titrations (curve 4), as the copper ions are removed in the form of precipitate, more mobile sodium ions along with $\mathrm{Na}_{2} \mathrm{SO}_{4}$, present in the titrant is introduced in the solution, and the conductance value starts increasing from the very beginning.

\section{Meta-vanadate titrations}

Sodium meta-vanadate solution was prepared by adding one mole of sulfuric acid to one mole of sodium ortho-vanadate solution at $100{ }^{\circ} \mathrm{C}$ and its reaction with $\mathrm{Cu}^{2+}$ has been investigated by performing both direct and reverse $\mathrm{pH}$ and conductometric titrations. The stoichiometric points obtained from the titration curves (Figure 3) indicate that $\mathrm{Cu}^{2+}$ and $\mathrm{VO}_{3}^{-}$ions combine in the ratio of 1:2 and suggest the formation of copper metavanadate $\mathrm{CuO} . \mathrm{V}_{2} \mathrm{O}_{5}$ around $\mathrm{pH}$ 6.2. The formation of the meta-vanadate can be represented as follows:

$$
\begin{aligned}
& \mathrm{H}_{2} \mathrm{SO}_{4}+\mathrm{Na}_{3} \mathrm{VO}_{4}=\mathrm{NaVO}_{3}+\mathrm{Na}_{2} \mathrm{SO}_{4}+\mathrm{H}_{2} \mathrm{O} \\
& \mathrm{CuSO}_{4}+2 \mathrm{NaVO}_{3}=\mathrm{CuO} \cdot \mathrm{V}_{2} \mathrm{O}_{5}+\mathrm{Na}_{2} \mathrm{SO}_{4}
\end{aligned}
$$

The feeble breaks obtained in reverse conductometric titration curves (Figure 3, curve 4) as a consequence of the appreciable increase in conductance values in the initial stages of titration indicate clearly the liberation of highly mobile $\mathrm{H}^{+}$ions and provide strong support to the observations noted in reverse $\mathrm{pH}$ titrations.

The reaction between copper sulfate and sodium polyvanadate was also studied, but the curves did not exhibit any appreciable break or inflection at the stoichiometric end-point. This may be ascribed to small difference in the $\mathrm{pH}$ values of reactants and the presence of $\mathrm{Na}_{2} \mathrm{SO}_{4}$ in appreciable amount in poly-vanadate solution; preventing occurrence of breaks in the conductometric titration curves.

It was noted that the presence of ethanol in copper vanadate titrations slightly improves the end-points and gives better results as it decreases solubility of the precipitates formed and minimizes hydrolysis and adsorption. $20 \%$ ethanolic medium was therefore employed for the entire course of the study. A thorough stirring in the vicinity of the end-point had a favorable effect.

\section{Analytical results}

The results of the quantitative elemental analyses of the precipitates were used to calculate the proportions of the elements present in the compounds. From these proportions, composition of the compounds was established which was found to be the same as obtained by the electrometric study (see Table 2).

As structure of these compounds is not known they are represented as double oxides, the manner which is usually adopted for such compounds..$^{22,23}$

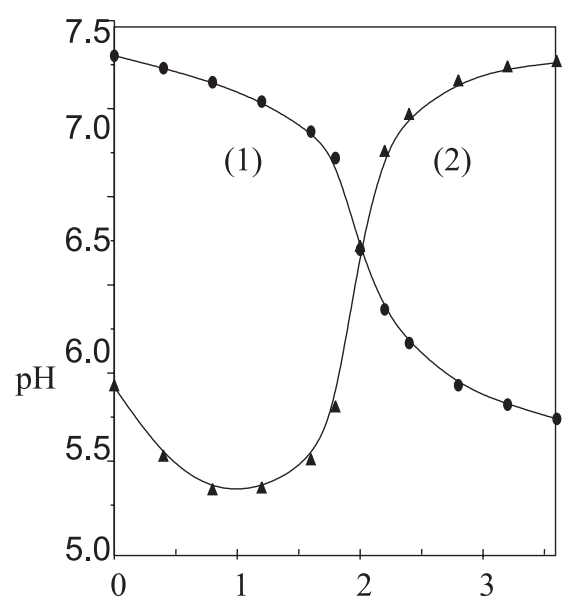

Vol. of titrant/ $\mathrm{mL}$

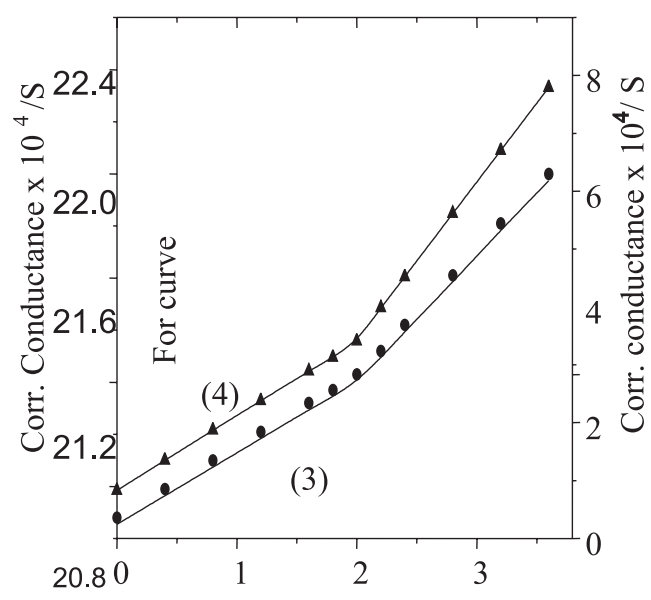

Vol. of titrant/ $\mathrm{mL}$

Figure 3. Meta-vanadate titrations. (1) and (3): $25 \mathrm{~mL}$ of $8.00 \times 10^{-3} \mathrm{~mol} \mathrm{~L}^{-1}$ of $\mathrm{NaVO}_{3}$ titrated with $5.00 \times 10^{-2} \mathrm{~mol} \mathrm{~L}^{-1}$ of $\mathrm{CuSO}_{4}$, (2) and (4): $25 \mathrm{~mL}$ of $8.00 \times 10^{-4} \mathrm{~mol} \mathrm{~L}^{-1}$ of $\mathrm{CuSO}_{4}$ titrated with $2.00 \times 10^{-2} \mathrm{~mol} \mathrm{~L}^{-1}$ of $\mathrm{NaVO}_{3}$ 


\section{Conclusion}

The present electrometric and analytical investigations on the interaction of copper sulfate with different sodium vanadates provide definite evidence for the formation of copper ortho-3CuO. $\mathrm{V}_{2} \mathrm{O}_{5}$, pyro- $2 \mathrm{CuO} . \mathrm{V}_{2} \mathrm{O}_{5}$ and meta$\mathrm{CuO} . \mathrm{V}_{2} \mathrm{O}_{5}$ vanadates in the vicinity of $\mathrm{pH} 8.7,7.4$ and 6.2, respectively.

\section{Acknowledgement}

The authors wish to express their sincere thanks to $\mathrm{CNPq}$ for financial assistance.

\section{References}

1. Hou, D.; New Chemistry of Polyvanadates in Non-aqueous and Aqueous Media, Emory Univ. Atlanta, GA, Aval. Univ. Microfilms Int., Order No. DA9505696, 1994, p. 229.

2. Odyakov, V.F.; Matveev, K.J.; Izobreteniya 1993, 47, 172.

3. Miesel, R.; German pat. 4,334,642 1995.

4. Crans, D.C.; Comments Inorg. Chem. 1994, 16, 1; ibid, 16, 35 .

5. Clark, R.J.H. In Comprehensive Inorganic Chemistry; TrotmanDickenson, A.F., ed.; Pergamon Press: Oxford, 1975, v. 3, p. 513.

6. Blasco, T.; López Nieto, J.M.; Appl. Catal. 1997, 157, 117.

7. Kung, H.H.; Adv. Catal. 1995, 133, 219.

8. Albonetti, S; Cavani; F.; Trifiro, F.; Catal. Rev.-Sci. Eng. 1996, 38,413 .
9. Centi, G.; Appl. Catal. A: General 1996, 147, 267.

10. Wachs, I.E.; Weckhuysen, B.M.; Appl. Catal. A: General 1997, 157, 67.

11. Khodakov, A.; Yang, J.; Su, S.; Iglesia, E.; Bell, A.T.; J. Catal. 1998, 177, 343.

12. Centi, G.; Perathoner,S.; Trifiro, F.; Aboukais, A.; Aissi, C.F.; Guelton, M.; J. Phys. Chem. 1992, 96, 2617.

13. Michalakos, P.; Kung, M.C.; Jahan, I.; Kung, H.H.; J. Catal. 1993, 140, 226.

14. Owens, L; Kung, H.H.; J. Catal. 1994, 148, 587.

15. Corma, A.; López Nieto, J.M.; Paredez, N.; J. Catal. 1993, 144,425

16. Kepert, D.L. In Comprehensive Inorganic Chemistry; TrotmanDickenson, A.F., ed.; Pergamon Press: Oxford, 1973, v. 4, p. 625.

17. Prasad, S.;Can. J. Chem. 1981, 59, 563.

18. Prasad, S.; Bull. Electrochem. 1990, 6, 163.

19. Prasad, S.; Quím. Nova 1994, 17, 31.

20. Prasad, S.; Gonçalves, S.B.; Brito, J.B.; Catalysis Today 2000, 57, 339.

21. Vogel, A.I.; A Textbook of Quantitative Inorganic Analysis, $3^{\text {rd }}$ ed., Longmans: London, 1968, p. 498, 791.

22. Standen, A. ed.; Kirk-Othmer Encyclopedia of Chemical Technology, $2^{\text {nd }}$ ed., Interscience Publishers: New York, 1967, v. 13, p. 782.

23. Brauer, G., ed.; Handbook of Preparative Inorganic Chemistry, $2^{\text {nd }}$ ed., Academic Press: New York, 1965, v. 2, p. 1705.

Received: October 29, 2001

Published on the web: August 1, 2002 